\title{
IS EAST ASIA AS PREPARED AS EUROZONE FOR MONETARY UNION?
}

\author{
Chee-Heong Quah \\ Faculty of Business and Accountancy, University of Malaya, Kuala Lumpur 50603, Malaysia \\ E-mail:quahch@um.edu.my
}

Received 26 January 2011; accepted 13 April 2011

\begin{abstract}
Based on optimum currency areas (OCA) theory and recent developments in the exchange rate regime literature, this paper evaluates the level of preparedness of East Asia for monetary integration by using the EMU as benchmark. Ten macroeconomic dimensions are explored in which the first five facets are measured relative to a reference country, namely the US, Japan, or China whilst the remaining five facets are measured in absolute terms, over the most recent years. In some ways, the exercise does signify the relative economic dominance of the three largest economies to the region. Results suggest that East Asia might be fairly prepared for a monetary integration especially when the reference country is the US. Another interesting observation is that amongst the eurozone founding members, Ireland has shown the lowest degree of conformity in a number of the criteria.
\end{abstract}

Keywords: Asia, US, Japan, China, Europe, monetary union, dollar, business cycle.

Reference to this paper should be made as follows: Quah, C.-H. 2012. Is East Asia as prepared as eurozone for monetary union?, Journal of Business Economics and Management 13(3): 471-488.

JEL Classification: C19, E32, F10, F15, F41, O53.

\section{Introduction}

In recent decades, there have been discussions on the feasibility of monetary integration in East Asia. Amongst the academics, Bayoumi and Eichengreen (1994), Goto and Hamada (1994), and Kawai and Takagi (2005) have once concluded that East Asia came as close as Western Europe to being a currency area. Quite the opposite, some authors such as Wilson and Choy (2007) have demonstrated that East Asian countries are structurally too different to constitute a monetary union. In the same vein, using Japan as the reference country, Font-Vilalta and Costa-Font (2006) found that despite increasing synchronization of macroeconomic determinants of a monetary area, the outlook of an Asian currency union is still not feasible. Though their results differ, the standard framework of analysis used hinges on the theory of optimum currency areas (OCA).

But then again, most empirical studies including those above concentrate on symmetrical economic shocks as the basis to indicate the prospects for integration. While shock 
symmetry analysis, a measure of cost of relinquishing national monetary policy is technically appealing, one pragmatic approach would be to directly compare East Asia to EMU in respect of the relevant dimensions in a "no-frills" manner.

Along these lines, based on OCA theory and recent developments in the exchange rate regime literature, this paper evaluates the level of preparedness of East Asia for monetary integration by using the founding member states of EMU as the benchmark ${ }^{1}$. A total of ten dimensions are explored in which the first five items are measured relative to a reference country, a prospective monetary anchor country for East Asia, whilst the remaining five facets are measured in absolute terms. Unlike Font-Vilalta and Costa-Font (2006) who utilized only Japan as the reference country, three alternative reference counries, namely the US, Japan, and China are considered here. In some ways, the exercise does signify the relative economic dominance of the three largest economies to the region. The findings suggest that East Asia might be fairly prepared for a monetary integration especially when the reference country is the US. Another observation is that amongst the eurozone founding members, Ireland has appeared to be the least conforming in a number of measures.

The remainder of this paper is organized as follows. The second section introduces the five reference-dependent dimensions and compares these features of East Asia against those of EMU using US, Japan, and China as alternative references for East Asia and Germany as the reference for EMU. The third section repeats the exercise with another five dimensions that are not measured against any reference. The fourth section concludes.

\section{Assessing monetary anchor country alternatives: US, Japan, and China}

The main tool used here is OCA theory. The foundations of the OCA theory were laid out by Mundell (1961) and McKinnon (1963), and then refined by Kenen (1969) and Krugman (1990). In essence, the OCA theory outlines the criteria under which a country or economic zone can reap large benefits and/or substantially reduce the cost of joining a currency area. As summarized by Boreiko (2003: 315):

The OCA theory concerns about certain benefits and costs associated with adopting a single currency which depend on the degree of convergence of the economies. The benefits are associated with economizing on exchange costs and importing the credibility of the union's central bank, thus reducing the inflationary expectations and level of inflation. As for the associated costs, they are essentially the opposite of the benefits of having an independent monetary policy and exchange rate, which are useful as a means of coping with shocks that are asymmetric between the potential monetary union partners. Akin to Quah and Crowley (2010), the OCA measures implemented in this section are

\footnotetext{
${ }^{1}$ The East Asian economies examined are Japan, Korea, China, Taiwan, Hong Kong, the Philippines, Thailand, Malaysia, Singapore, and Indonesia. The European Economic and Monetary Union (EMU) countries included are Germany, Austria, Belgium, Finland, France, Ireland, Italy, Luxembourg, the Netherlands, Portugal, and Spain where Germany acts as the reference country in the analysis in Section 2.
} 
bilateral trade intensity, business cycle symmetry, inflation convergence, real exchange rate volatility, and real interest rate synchronization. These criteria were implemented earlier by Artis and Zhang (2002) and interestingly the efficacy of the criteria was proven when Portugal, Italy, Greece, and Spain were accurately distinguished as a group maintaining least conforming OCA features against Germany, which reflects the distressed eurozone members today.

Following the model used by Artis and Zhang (2002) for Western Europe, these dimensions are measured against a reference country. The designation of a reference country for East Asia is extremely practical, for ease of transition and enhanced credibility in the stages toward a possible Asian monetary union. Due to the absence of institutional, political and economic groundwork such as that exists in the European Union, a monetary anchor would enable East Asia to leap-frog toward a currency area if potential members, including Japan were willing to entertain the use of a monetary anchor (Mundell 2003). In particular, due to political difficulties, integration might be relatively easier if the exchange rates are jointly fixed to an anchor at the initial stage of integration as many of the countries have experiences in pegging or fixing their exchange rates (mostly to the dollar, see e.g. McKinnon, Schnabl 2004) in the past.

Meantime, there are serious impediments for adopting a common currency basket if major currencies continue to be highly volatile ${ }^{2}$ as it would (1) entail complex hedging strategies; (2) suggest that authorities maintain sufficient liquidity in not just one but a few major currencies in order to keep their currencies sufficiently close to the target values defined by the common basket; and (3) require picking the appropriate official weights for a common basket, which could be extremely problematic. Since virtually all Asian nations have experienced with exchange rate pegging (to the dollar), it should be relatively easier if a single monetary anchor is chosen than the case of a common currency basket.

In light of the above, the features of each East Asian country are measured against and compared over three reference countries, namely US, Japan, and China. In addition to that, the levels of conformity to OCA theory are also compared to those of euro founding members in which Germany plays the reference. US is selected as one reference for East Asia because of its hegemonic dollar standard whilst Japan is chosen because of its dominant role in trade and FDI across Asia which had begun far before China opened up its doors. China is of course one possible reference country since its rise to becoming an economic powerhouse.

In addition to the above facets, in the third section, other dimensions which are not reference-dependent are also examined. For all variables, the data sampled are constrained by data availability but generally ranged from 1999 to 2009, the period after the Asian turmoil but inclusive of the recent global crisis. Since the period examined covers the actual implementation period of unified exchange rates in the EMU, benchmarking against the euro founding countries should be appropriate in light of the endogeneity view of convergence criteria (Frankel, Rose 1998). Should the criteria are indeed

\footnotetext{
${ }^{2}$ For a good explanation see McKinnon and Schnabl (2004).
} 
endogenous, East Asian countries exhibiting features as conforming as the EMU ones would have added advantage for monetary unification. Except for the business cycle and interest rate criteria, period averages are used for all variables.

\subsection{Bilateral trade intensity}

Mundell (1961) and McKinnon (1963) assert that countries which trade a great deal with each other are good candidates for monetary integration as the gains from transaction cost savings and exchange rate certainty would be more than offset the shock absorbing benefits of flexible exchange rate. Empirically, Bayoumi and Eichengreen (1997) have detected that European countries which maintained the greatest levels of bilateral trade also experienced the greatest increase in their readiness for monetary unification. As put it by Edison and Melvin (1990), in choosing which currency to peg to, a country should emphasize a bilateral trade criterion. Thus, it is obvious to use this facet as one criterion to assess the desirability of adopting US, Japan, or China as the monetary anchor country. For every country $i$, trade openness with the reference country (i.e. US, Japan, or China for East Asia and Germany for eurozone) is measured by bilateral trade intensity, $\left(x_{i, r}+m_{i, r}\right) /\left(x_{i}+m_{i}\right)$ where $x_{i}$ and $m_{i}$ are the exports and imports of goods of the country and subscript $r$ indicates destination to or source from that reference country.

Figure 1 portrays the degrees of trade linkages with US, Japan, and China in East Asia and those with Germany in euro area. Let us first explore the values across the refer-
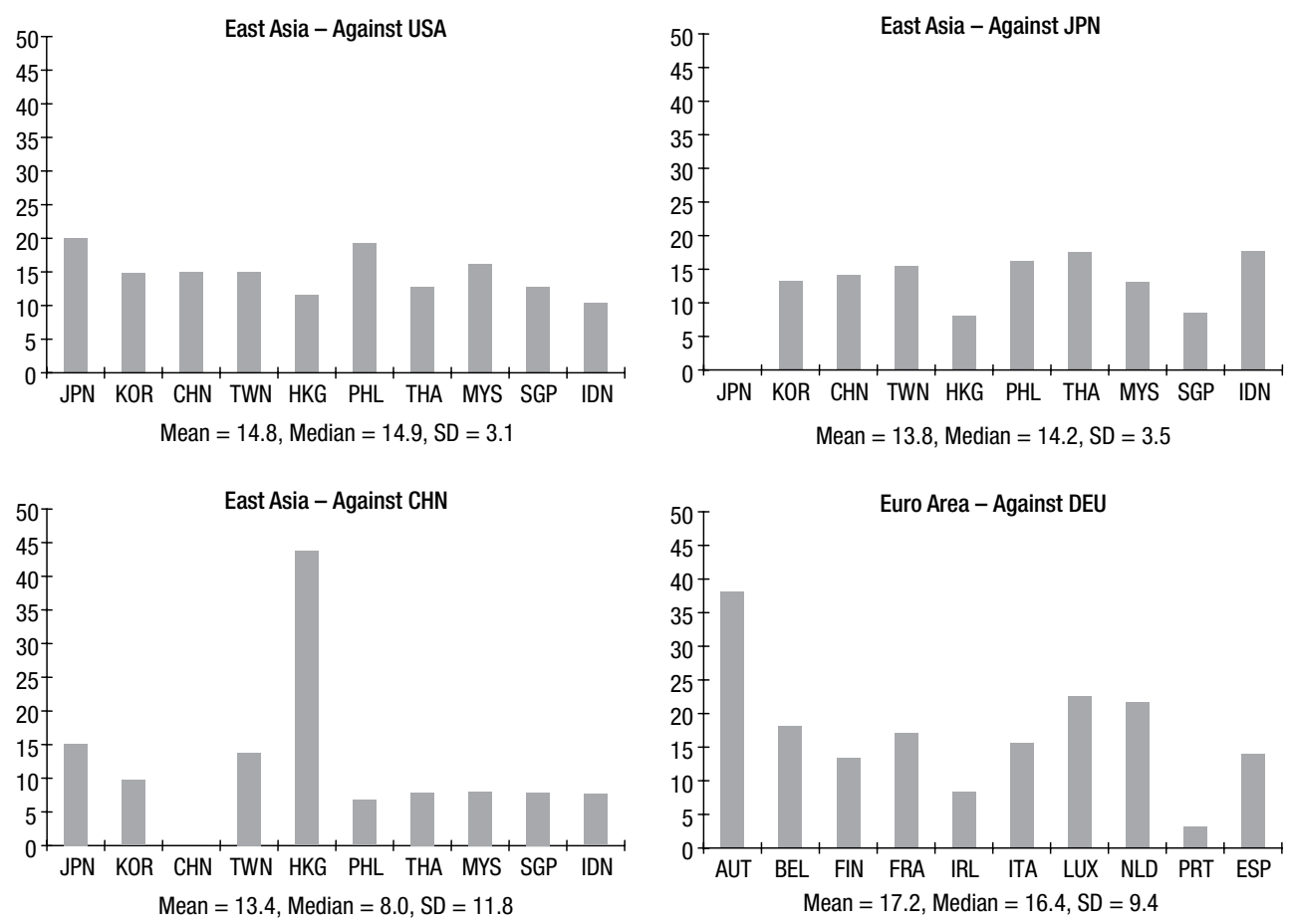

Fig. 1. Bilateral trade intensity (\%), 1999-2009

Source: IMF: DOTS; Taiwan National Statistics 
ences of US, Japan, and China. As the vertical bars and the mean and median values indicate, the overall trade intensity with US is greater than that with Japan and that with Japan is higher than that with China. Signified by standard deviation, the levels of trade intensity with US are also the most homogeneous. Remarkably in East Asia, Japan and the Philippines trade the most with US. Of all observations, the largest trade linkage is that between Hong Kong and China which is extremely high in absolute terms; this is not surprising given Hong Kong's geographical and political proximity to China.

Looking at the euro members, only the Austrian trade level with Germany is visibility greater than any of those with US in East Asia. In addition, one can also notice the smallness of degree of trade with Germany from Ireland and Portugal. Though the mean and median of the euro area are somewhat greater than those of East Asia, the variation across the euro members is also much larger. Along these lines, the findings seem to suggest that trade levels against US (or even Japan) in East Asia are not only comparable to but are also more symmetrical than those against Germany in eurozone.

\subsection{Business cycle synchronization}

When business cycles are substantially synchronous between two countries, the argument for flexible exchange rates which serve as a shock absorber to resolve asymmetric recessionary or inflationary pressures becomes largely irrelevant ${ }^{3}$. In this case, for every country in East Asia, the higher the business cycle synchronicity with either US, Japan or China, the stronger the argument for adopting the monetary policy of that country. In terms of measurement, it has become popular to implement this OCA criterion according to the synchronicity of business cycles, that is, by evaluating the correlation coefficients of the cyclical component of real output series. Here, the method of Gerlach (1988) and Baxter and Stockman (1989) is adopted where cyclical components of annual real GDP series are detrended using Hodrick-Prescott (H-P) filter. For all cases, annual GDP series at 2005 prices are used.

Figure 2 depicts the business cycle synchronicity findings. Clearly, business cycles in East Asia are almost equally highly synchronous to the US and the Japanese cycle but are less parallel to the Chinese cycle. Indeed, except for China, Indonesia, and Korea, the degrees of business cycle symmetry with US or Japan appear to be comparable to those with Germany in eurozone. Notably, the Japanese cycle is significantly parallel to the US one but the Chinese cycle is weakly synchronous to the US cycle ${ }^{4}$. In this regard, it might be relatively easy for Japan but difficult for China to synchronize with the US in economic policies. Note also that the Indonesian cycle is highly synchronous with the Chinese cycle but extremely asynchronous with the US and the Japanese cycle. Incidentally, Ireland maintains the lowest degree of business cycle symmetry with Germany.

\footnotetext{
${ }^{3}$ Whilst similarity of trade and industry is important so that shocks become more symmetric across countries, it is the resulted outcome of business cycle movement which is ultimately critical as a measure of similarity of shocks and it is adequately captured by the business cycle symmetry dimension presented in the paper.

${ }^{4}$ Given the high trade intensity between Japan and US, the high Japan-US synchronicity could have been transmitted through trade.
} 

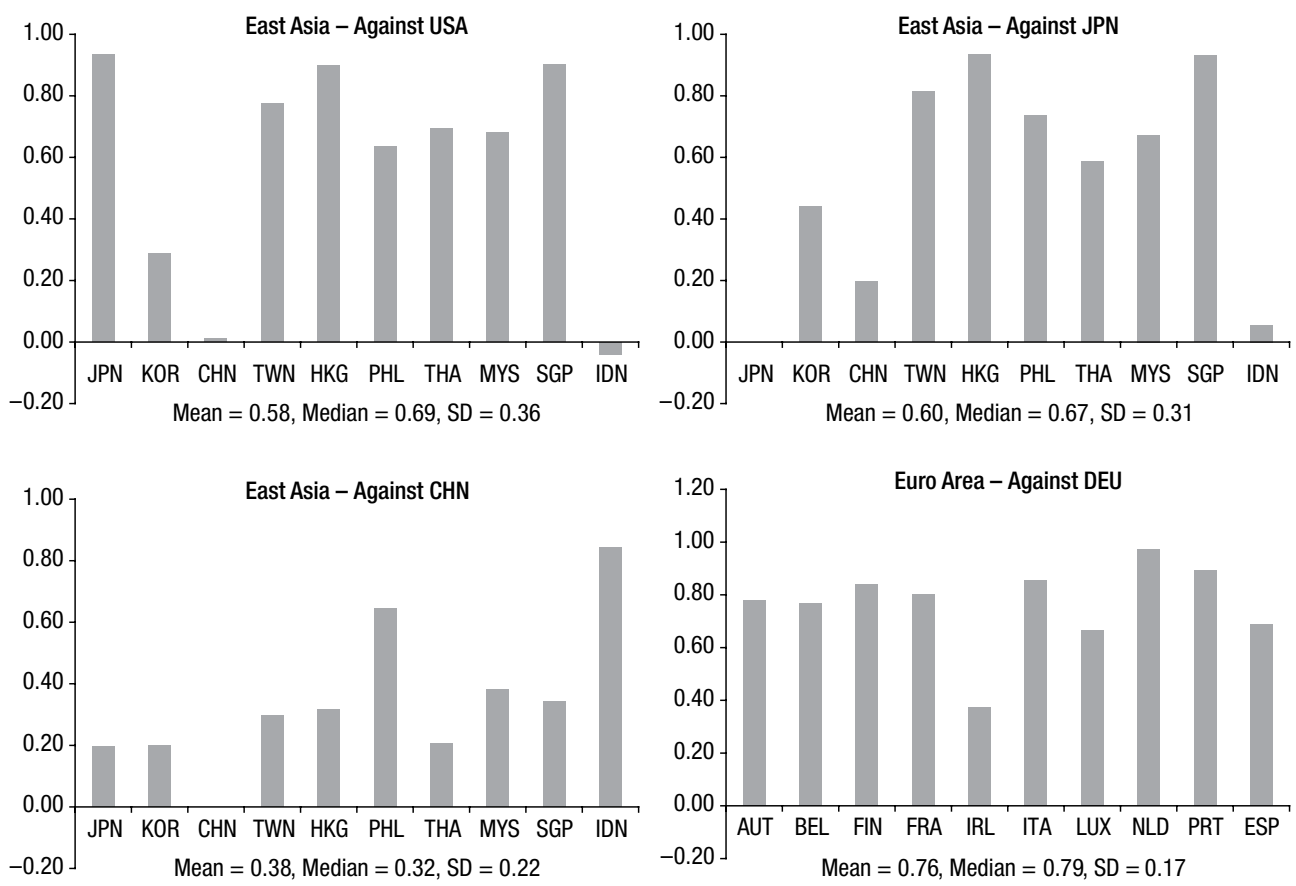

Fig. 2. Business cycle synchronization, 1999-2008

Source: WB: WDI; Taiwan National Statistics

\subsection{Inflation convergence}

According to Artis and Zhang (2002), the traditional OCA literature originated during the era of "fix-price" economics, so introducing inflation convergence as a criterion could be regarded simply as an appropriate normalization. From another perspective, since similar inflation rates result from similarities in economic structure and policy stance, the cost of joining a currency area is presumably low when inflation rates are similar across members (Nguyen 2007). Convergence in inflation also reflects similarity in trade union aggressiveness and labor costs between countries - implying less need for flexibility in nominal exchange rates to correct trade imbalances (Fleming 1971). Meanwhile, convergence of inflation rates is of course the central theme of Maastricht Treaty. This criterion is measured by the absolute CPI inflation differential, $\left|x_{i}-x_{r}\right|$ where $x_{i}$ and $x_{r}$ are the respective rates of inflation in country $i$ and the reference country. The absolute value is used since the magnitude of the measure is of concern here. Lower differential indicates greater convergence in inflation toward the reference level and vice versa.

Figure 3 demonstrates the inflation differential findings. It is apparent that the degrees of inflation convergence in the euro area are significantly greater than those in East Asia regardless of the reference country. Nonetheless, relative to those with Japan or China, inflation differentials with US not only maintain the lowest mean and median but also the smallest standard deviation. Hence, the levels of inflation convergence in the region should be greater and more symmetrical against US. Amongst the euro members, Ireland is once again most divergent from Germany. 

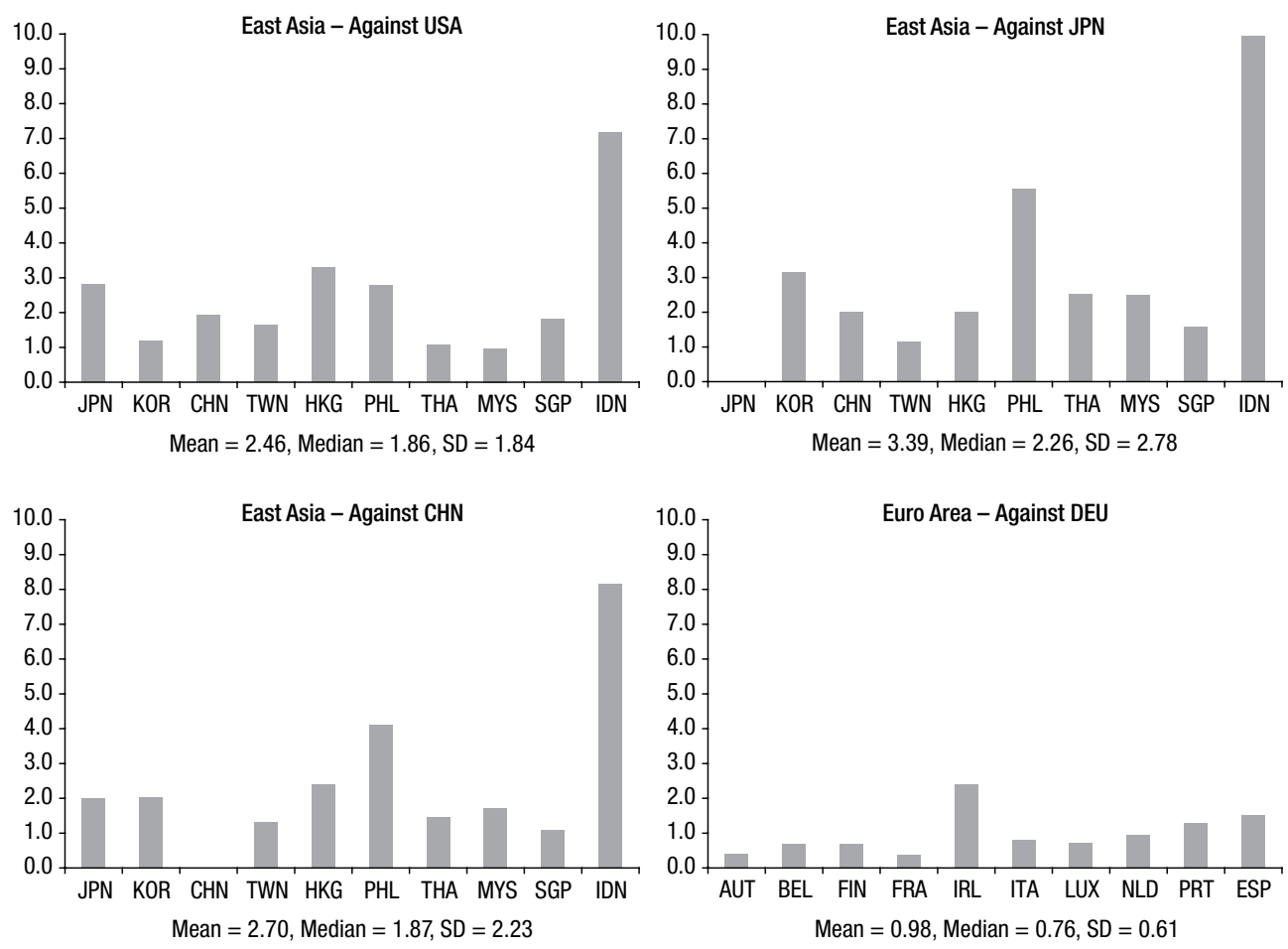

Fig. 3. CPI inflation differential (\%), 1999-2009

Source: IMF: IFS; Taiwan National Statistics

\subsection{Real exchange rate volatility}

The level of a country's need for real exchange rate changes is an important determining factor for joining a monetary union because real exchange rate changes are clearly measurable and automatically give the appropriate weights to the economic forces of which they are the result (Vaubel 1978). These economic forces pertain to inflation rates, openness, economy size, prices, wage flexibility, factor mobility, commodity diversification, goods market integration, and fiscal integration (Tavlas 1993). Hence, as Artis and Zhang (1997) put it, low real exchange rate volatility might indicate absence of asymmetric shocks and presence of business cycle conformity that may strengthen the case for a currency area. Here, volatility in real exchange rate is represented by the standard deviation of the log-difference of monthly real bilateral exchange rates against the reference country, where the deflator is relative consumer prices. For EMU countries, since nominal exchange rates are unified, real exchange rates are equivalent to relative consumer prices against Germany.

Figure 4 displays the real exchange rate volatility charts. Undoubtedly, most likely due to fixed nominal exchange rates in eurozone, the real exchange rates of the EMU member states are highly stable, much more stable than those in East Asia. In Asia, the variability levels of the real rates with US are the smallest. This seems to be consistent 

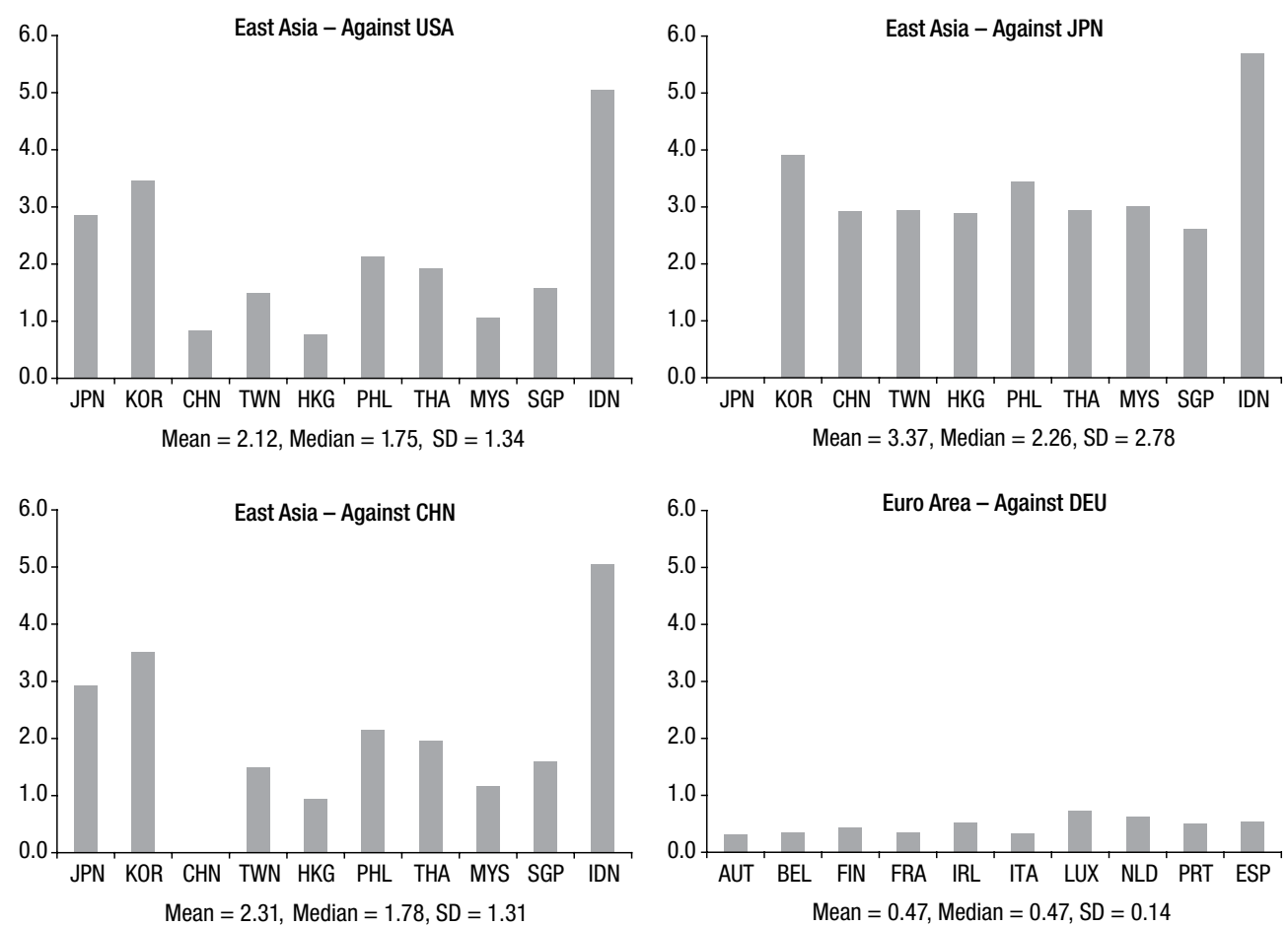

Fig. 4. Standard deviation of real bilateral exchange rate $(\times 100), 1999: 1-2009: 12$ Source: IMF: IFS; Taiwan National Statistics

with the return to the dollar standard in East Asia after the Asian crisis (see McKinnon, Schnabl 2004). Though the volatility levels with Japan are high, they are highly homogenous across countries. As expected, due to the (soft) yuan-dollar peg, the levels of volatility with China highly resemble those with US.

\subsection{Real interest rate synchronization}

Though not listed as one of the criteria based on the traditional OCA theory, this factor is indicated by a "revealed preference" argument (Artis, Zhang 2002). If the monetary policy of a candidate country historically has differed little from that of the reference country, the cost of eschewing monetary independence is accordingly low, so that synchronization in real interest rates may be interpreted as an indicator of coordination in monetary policy. From another perspective, real interest rate cycle synchronicity with a credible country could imply willingness to commit to policies of high counterinflationary credibility (Tavlas 1993). Similar to Artis and Zhang, real interest rate series are detrended by applying the H-P filter as in the business cycle synchronicity criterion ${ }^{5}$.

\footnotetext{
${ }^{5}$ Constrained by data availability, monthly money market rates and CPI inflation rates are used except for China, Belgium, France, and Netherlands where lending rates are used. For Austria, Luxembourg, and Portugal, adequate data are not available.
} 

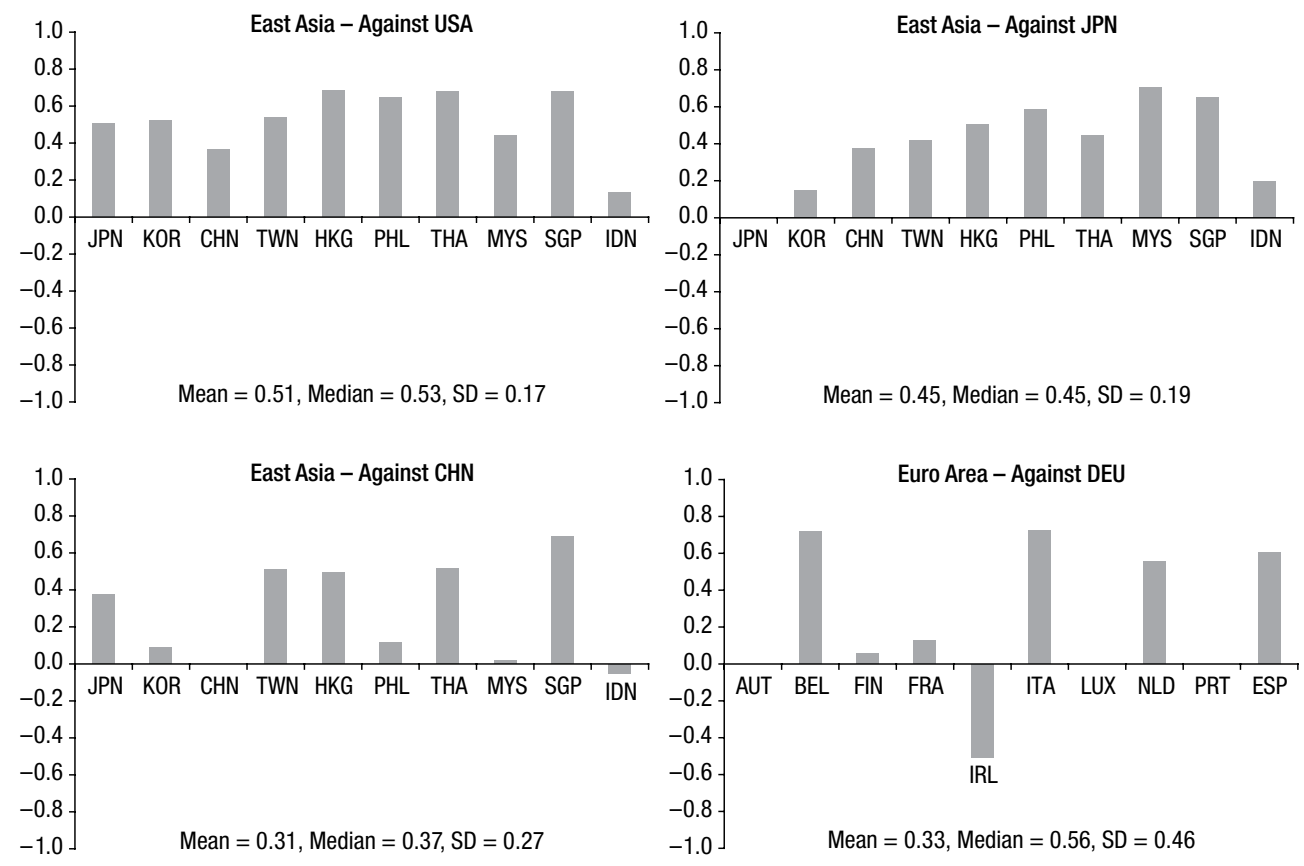

Fig. 5. Real interest rate cycle synchronization, 1999:1-2009:12

Source: IMF: IFS; Taiwan National Statistics

Figure 5 collects the charts depicting interest rate cycle synchronicities. On the whole, the degrees of symmetry of the Asian countries against either US or Japan are not only significantly greater and more homogenous than those against China but also than those against Germany in euro area. Between US and Japan, levels of symmetry with US are slightly higher than those with Japan. Amongst euro members, Ireland, maintaining a significant negative correlation is once again most divergent from Germany.

\section{Assessing non-reference dependent factors}

While the above features are evaluated relative to a reference country and hence may indicate the appropriate monetary anchor for East Asia, the variables explored in this section are measured in absolute terms, to assess whether exchange rate fixation would be supported regardless of monetary anchor.

\subsection{Openness to trade}

Amongst the early scholars on exchange rate regime, McKinnon (1963) emphasized the importance of a country's openness to trade as one predominant factor under which the greater the openness of an economy the greater the appropriateness of fixing the exchange rates. Besides the gains from transaction cost savings, stable exchange rates could also contribute to stable domestic prices. For a highly open economy, prices of exportables and importables are highly indexed to exchange rates such that depreciations (particularly repeated ones driven by downward expectations) of national currency 

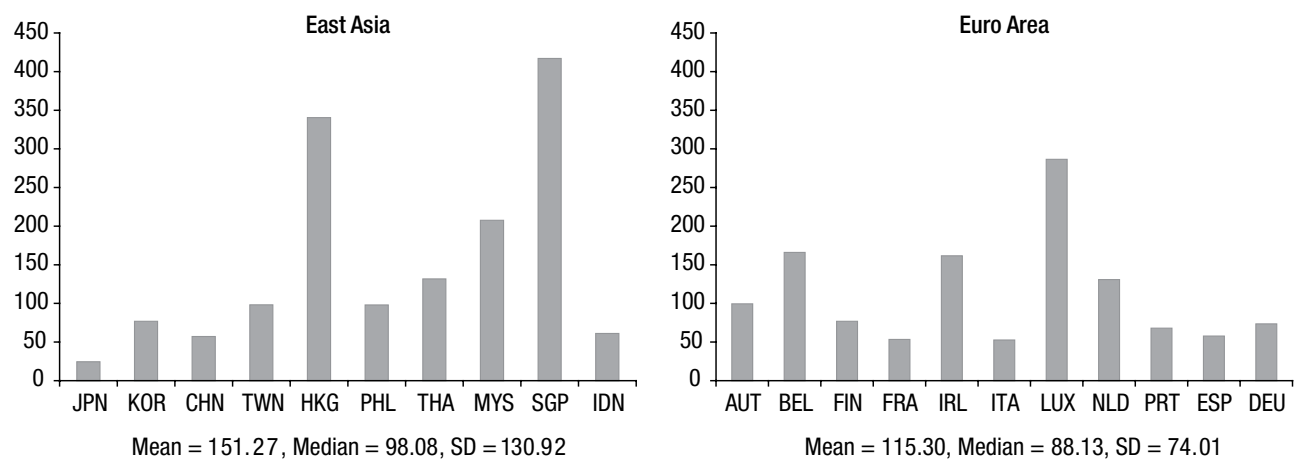

Fig. 6. Trade to GDP (\%), 1999-2008

Source: WB: WDI; Taiwan National Statistics

would raise the prices of domestic baskets of goods constituting primarily of these tradable goods. On the contrary, continuous appreciations might lead to unemployment. To account for this dimension, unlike the trade criterion used earlier to indicate the relative importance of a trading partner country, a general measure for openness, namely the percent of trade of goods and services to GDP is used here (see Fig. 6). Results show that other than Japan, East Asian countries are at least as open as the EMU members with exceptionally high openness to trade maintained by Hong Kong and Singapore.

\subsection{Diversification in exports}

While McKinnon (1963) stresses the significance of economic openness, Kenen (1969) highlights the importance of diversification in exports in deciding whether to fix the exchange rates. For a diversified economy, even if each of its export sectors might be subject to adverse shocks, if the shocks are substantially independent and the country produces a sufficiently large variety of different goods, the law of large numbers will come into play and total income will not suffer much. Thus, it is easier to fix the currency value in a diversified economy than that of a specialized economy. Following Nguyen (2007), the degree of export diversification is measured by a diversification index, namely the inverse of the period average of the annual Herfindahl index which is a popular indicator of the degree of specialization. The Herfindahl index is computed as $H=\sum_{i=1}^{n} s_{i}^{2}$ where $s_{i}$ is share of the export of product $i$, and $n$ is the number of products exported. The higher the value of this diversification index, the more diversified the exports. Since data of individual export products are unavailable, annual export data according to the first-digit sub-industries of the United Nation Standard International Trade Classification (SITC) Revision 2 are used. The categories are displayed in Table 1. Figure 7 displays the findings and undoubtedly the exports of Western European countries are significantly more diversified than those of the Asian countries. This is expected given the stage of industrialization and economic development in Western Europe. The less symmetrical levels of diversification in East Asia may also imply the more varied levels of industrialization in the region. Amongst East Asian economies, the most diversified exports are from Indonesia, Thailand, and China whereas the least diversified ones are from the Philippines, Japan, and Singapore. In EMU, Ireland is least diversified. 
Table 1. United Nation's Standard International Trade Classification (SITC) Revision 2

\begin{tabular}{cl}
\hline Codefigure 1 & \multicolumn{1}{c}{ Product type } \\
\hline 0 & Food and live animals \\
\hline 1 & Beverages and tobacco \\
\hline 2 & Crude minerals, inedible, except fuels \\
\hline 3 & Mineral fuels, lubricants, and related materials \\
\hline 4 & Animal and vegetable oils, fats and waxes \\
\hline 5 & Chemicals and related products \\
\hline 6 & Manufactured goods classified chiefly by material \\
\hline 7 & Machinery and transport equipment \\
\hline 9 & Miscellaneous manufactured articles \\
\hline
\end{tabular}

Source: Nguyen (2007)
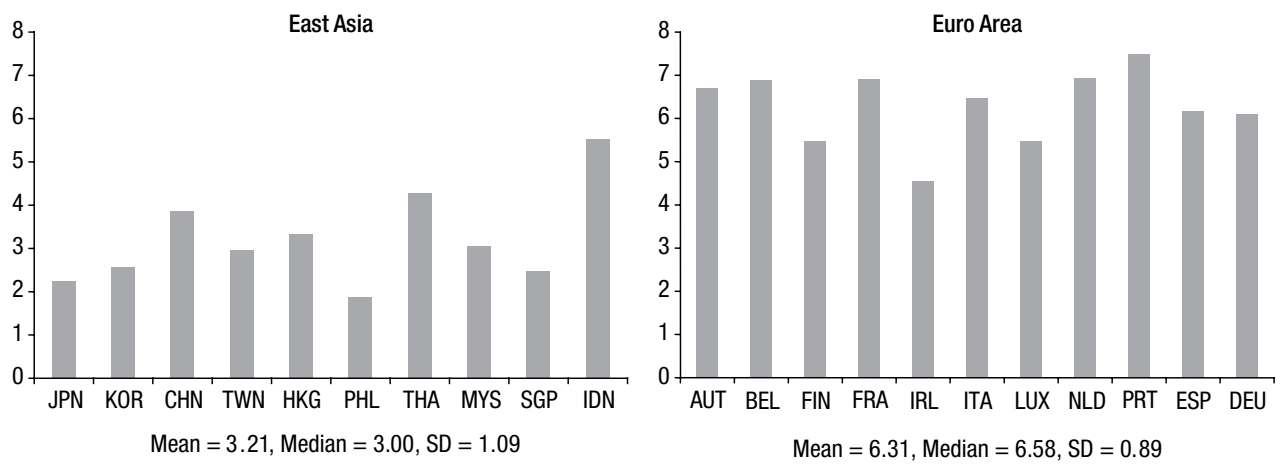

Fig. 7. Export diversification index, 2001-2009

Source: International Trade Center: Trade Map database

\subsection{Labor market flexibility}

Ingram (1962) and Kenen (1969) argued that domestic labor market flexibility is equally important to transnational labor mobility (popularized by Mundell 1961) to restore equilibrium in the labor markets from adverse shocks; the higher the flexibility of the labor market, the greater the ability to recover from unemployment shock, the greater the feasibility of locking the exchange rates. One measure of rigidity of labor markets that has been used in the literature is a ranking measure of the severity of employment protection legislation (see Artis, Zhang 2002). In the same vein, due to data constraints we use the average of the indexes measuring labor market rigidity by World Bank Doing Business Project to signify labor market flexibility - the smaller the average values the greater the levels of flexibility (see Table 2 and Botero et al. 2003). 
Table 2. Employing workers index definitions

\begin{tabular}{lll}
\hline \multicolumn{2}{c}{ Index } & \multicolumn{1}{c}{ Definition } \\
\hline 1 & Difficulty of hiring & Difficulty of hiring a new worker \\
\hline 2 & Rigidity of hours & $\begin{array}{l}\text { Restrictions on expanding or contracting the number } \\
\text { of working hours }\end{array}$ \\
\hline 3 & Difficulty of redundancy & Difficulty and expense of dismissing a redundant worker \\
\hline 4 & Rigidity of employment & Nonwage worker remuneration in percent of salary \\
\hline
\end{tabular}

Source: Botero, Djankov, La Porta, Lopez-de-Silanes, and Schleifer (2003)
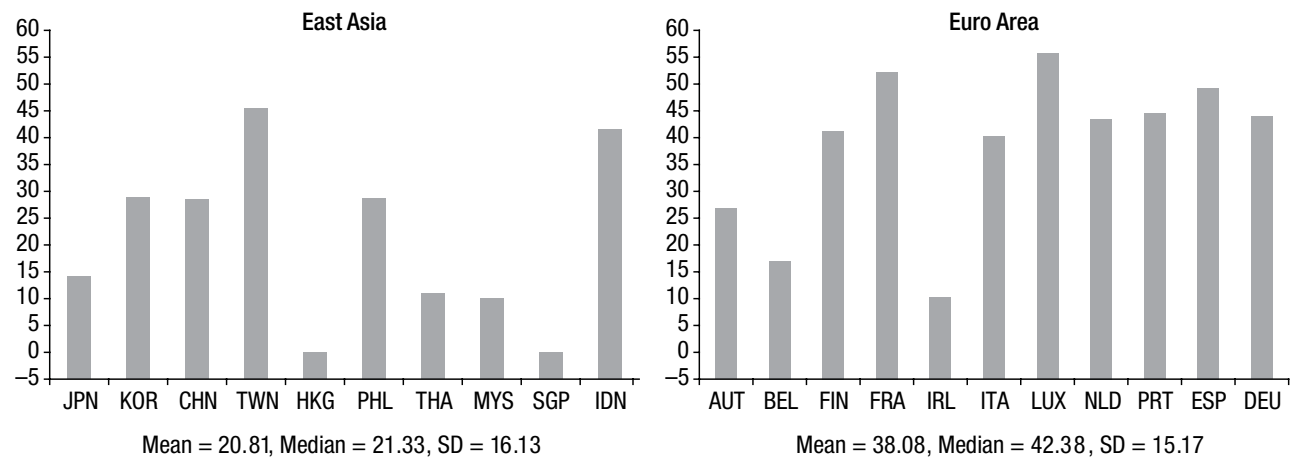

Fig. 8. Labor market rigidity index (0-100), 2004-2010

Source: WB: Doing Business database

Figure 8 displays the findings. On the whole, labor markets in East Asia are more flexible than those in eurozone. This finding corroborates Bayoumi and Mauro (2001) who argued that domestic labor markets in East Asia are more flexible than those in Western Europe and therefore, though the size of supply disturbances had been larger in East Asia, the speed of adjustment to shocks was much faster than that in Europe. In particular, Hong Kong and Singapore boast the most flexible labor markets. In the eurozone, Ireland possesses the most flexible labor market, and perhaps for this reason it has remained in the eurozone in spite of its domestic problems and despite its lack of trade and lack of symmetry with Germany in the inflation, business cycle, and interest rate dimensions.

\subsection{Fiscal restraint}

In light of the recent fiscal and government debt debacle in EMU, it is instructive to evaluate the Maastricht criterion of fiscal restraint amongst the East Asian economies. This criterion can be justified by moral hazard in a monetary system with fiscal independence to member states. This is so because a member can choose to run precariously high budget deficits and accumulate unsustainable levels of debt, expecting other members to bear some of the consequences. Quite the opposite, in the absence of mon- 
etary union, the national government with such imprudent policies would be subjected to higher interest rates instead of lower union-wide interest rates. Along these lines, Asian countries maintaining healthy public finances would have greater fiscal flexibility against asymmetric economic shocks should an Asian union is formed.

Figure 9 displays general government budget balances as percent of GDP where positive values indicate surplus and negative values represent deficit. Meantime, Figure 10 exhibits the public debt stocks as percent of GDP. Since there are extreme negative value of Japan and positive value of Singapore in the budgetary balances in East Asia, it is more appropriate to look at the values of the median instead of the mean. Based on the median, government budget deficits in East Asia are somewhat higher than the European ones. With regards to public debt levels, even when the extremely high value of Japan is included, the mean and median values still signify that the indebtedness levels in East Asia are lower than those in Europe. Interestingly, whilst Singapore reports a very high budget surplus, it also maintains high debt level. In the eurozone, noticeably high deficit and debt levels are shown by Italy.
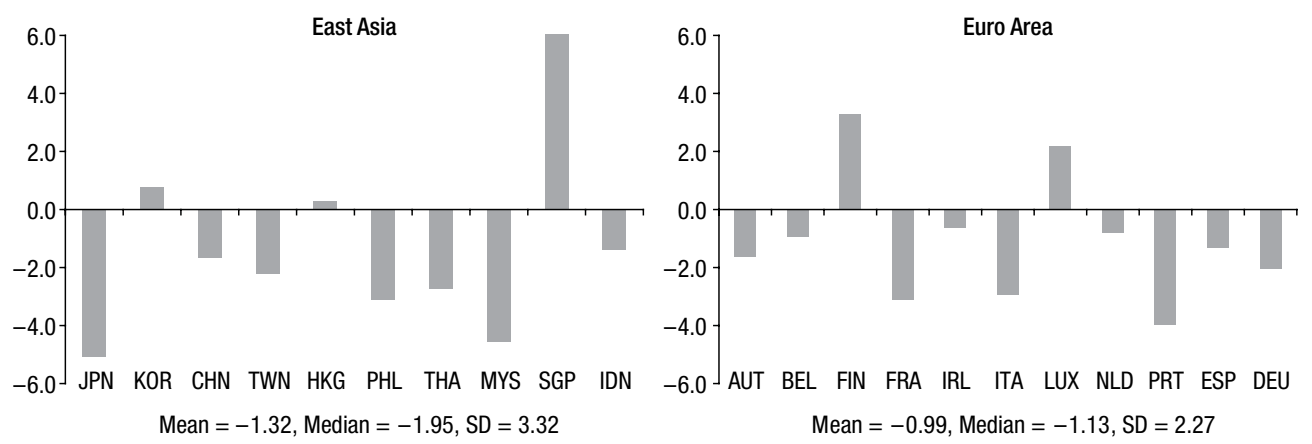

Fig. 9. General government budget balance (\% of GDP), 1999-2009

Source: ADB and Eurostat databases
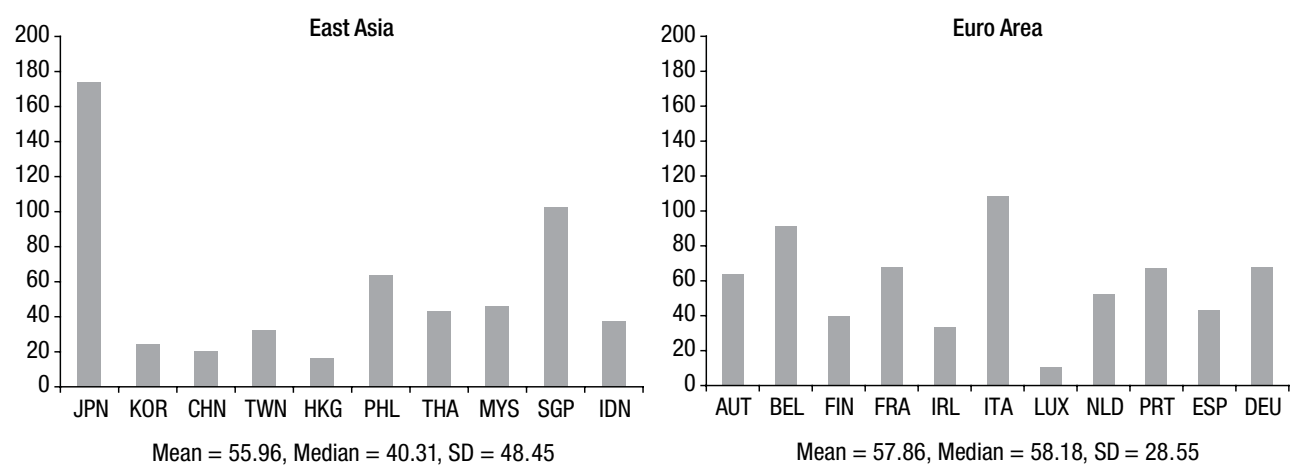

Fig. 10. Public debt to GDP (\%), 2005-2007, 2009

Source: CIA: World Factbook, various issues 


\subsection{Reserves adequacy}

To complement the analysis, it may also be compelling to look at a measure which reflects the significance of international capital flows of which, according to Boreiko (2003), has somewhat been neglected by the OCA literature.

As postulated by the currency crisis model of exchange rate regime, the collapse of a pegged exchange regime is associated with a steady erosion of international reserves (Markiewicz 2006). The attack on a currency depletes reserves and forces the authorities to abandon the parity. Hence, the country choosing to peg its exchange rate but still maintaining national currency (might be the case for a possible Asian monetary union) must possess substantial amount of reserves to insure the credibility of the fixed peg. To account for this facet, we introduce the ratio of total reserves to M2 as displayed in Figure 11. A similar measure was used by Calvo (1998) for the purpose. Constrained by data availability, aggregate data for euro area of which the number of member states var-

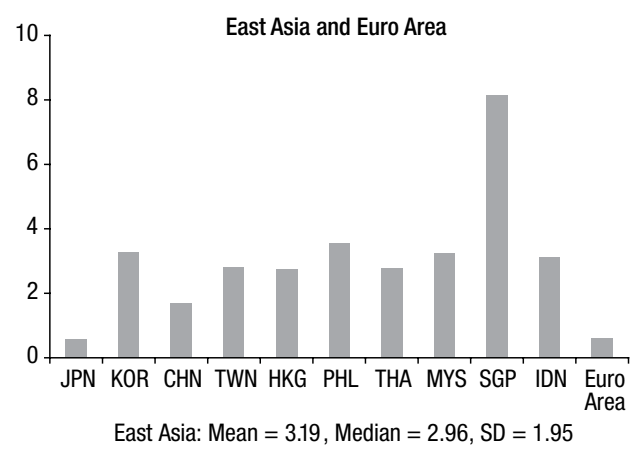

Fig. 11. Total reserves to $M 2$ ratio $(\times 10)$, 1999-2008 Source: WB: WDI; IMF: IFS ies over the sample period are used. The results show that except for Japan, all other East Asian economies have greater reserves ratios than eurozone has. Notably, Singapore reports an exceptionally high level of reserves level which might be needed to facilitate its peg against an undisclosed basket of currencies and its position as an international financial hub. Meanwhile, the low reserves levels of Japan and euro area might be supported by the reserve currency status of their yen and euro and their ability to borrow in their own domestic currencies.

\section{Conclusion}

Besides assessing the level of preparedness for monetary union, the first part of the analysis has evaluated as to which amongst the three largest economies today, the US, Japan, and China would be a more fitting monetary anchor country for East Asia using five reference-dependent variables and EMU as benchmark. In some ways, it could infer the relative importance of the economies to the region. Using the same approach, the second part of the analysis investigated another five dimensions but which do not depend on any reference country. The following Table 3 summarizes the main findings.

Based on the findings from the first five dimensions, in terms of potentiality of being the monetary anchor country, US seems to be somewhat better than Japan whilst Japan appears to be better than China ${ }^{6}$. Nonetheless, the degree of compliance to the criteria in East Asia using any of the reference countries seems to be at most only as high as that in EMU, depending on the dimension in question.

\footnotetext{
${ }^{6}$ Comparable conclusion can be found in Quah and Crowley (2011).
} 
Table 3. Summary of findings

\begin{tabular}{|c|c|c|}
\hline & Dimensions & Main Findings \\
\hline 1 & $\begin{array}{l}\text { Bilateral trade } \\
\text { intensity }\end{array}$ & $\begin{array}{l}\text { Trade linkages of East Asia with US and Japan are comparably } \\
\text { large and lower but more homogenous than those of EMU. } \\
\text { Japan trades highly with US. In euro area, Ireland } \\
\text { and Portugal trade the least with Germany }\end{array}$ \\
\hline 2 & $\begin{array}{l}\text { Business cycle } \\
\text { synchronization }\end{array}$ & $\begin{array}{l}\text { Business cycle symmetry levels of East Asia with US and Japan } \\
\text { comparably high. A substantial number of economies exhibit } \\
\text { symmetry levels at least as high as those in EMU. Japan } \\
\text { is significantly parallel to US. In euro area, Ireland maintains } \\
\text { the lowest degree of symmetry with Germany }\end{array}$ \\
\hline 3 & $\begin{array}{l}\text { Inflation } \\
\text { convergence }\end{array}$ & $\begin{array}{l}\text { Levels of inflation convergence with US the highest and most } \\
\text { homogenous in relation to those with Japan or China but still lower } \\
\text { and less homogenous than those in EMU. In eurozone, the Irish } \\
\text { inflation is most divergent from the German one }\end{array}$ \\
\hline 4 & $\begin{array}{l}\text { Real exchange rate } \\
\text { volatility }\end{array}$ & $\begin{array}{l}\text { Levels of variability against US and China equally low but not } \\
\text { lower than those in eurozone }\end{array}$ \\
\hline 5 & $\begin{array}{l}\text { Real interest rate } \\
\text { cycle symmetry }\end{array}$ & $\begin{array}{l}\text { Levels of interest rate symmetry with US are slightly higher than } \\
\text { those with Japan and the levels of symmetry with either US or } \\
\text { Japan are larger than those with China and those in EMU. } \\
\text { In eurozone, Ireland is most divergent from Germany }\end{array}$ \\
\hline 6 & Openness to trade & $\begin{array}{l}\text { Degrees of openness to trade in goods and services in East Asia are } \\
\text { at least as high as those in EMU }\end{array}$ \\
\hline 7 & $\begin{array}{l}\text { Diversification in } \\
\text { exports }\end{array}$ & $\begin{array}{l}\text { Levels of export diversification in East Asia are significantly lower } \\
\text { than those in EMU. In eurozone, Ireland is least diversified }\end{array}$ \\
\hline 8 & $\begin{array}{l}\text { Labor market } \\
\text { flexibility }\end{array}$ & $\begin{array}{l}\text { Levels of flexibility in East Asia higher than those in EMU. } \\
\text { In eurozone, the Irish labor market is the most flexible }\end{array}$ \\
\hline 9 & Fiscal restraint & $\begin{array}{l}\text { Budget deficits in East Asia are somewhat higher than those in } \\
\text { EMU but debt levels in East Asia are lower than those in Europe. } \\
\text { In the eurozone, high deficit and debt levels are reported by Italy }\end{array}$ \\
\hline 10 & Reserves adequacy & $\begin{array}{l}\text { Except Japan, all East Asian economies have greater levels } \\
\text { of reserves adequacy than that in eurozone }\end{array}$ \\
\hline
\end{tabular}

The latter five dimensions however, appear to suggest that the East Asian economies are at least as prepared as EMU founding members for fixed exchange rates or monetary integration. Putting the findings from all the dimensions together, East Asia might be fairly prepared economically for a monetary integration especially when the monetary anchor country is the US. This seems to corroborate Quah and Crowley (2010) who detected increased convergence in the region against the US but contradict Yamashita (2009) who called for Asia to de-dollarize in the path toward an Asian monetary system. Nonetheless, the findings here are consistent with the conclusion by Font-Vilalta and Costa-Font (2006) who used Japan as the reference country that East Asia is not economically feasible for a monetary union. 
Another important observation is that despite exhibiting the lowest degree of conformity in most of the features relative to Germany and the least diversified exports, Ireland maintains the most flexible labor market amongst the EMU member states. This feature might have alleviated some of the adverse asymmetric impacts experienced by Ireland against the hegemonic Germany in the euro system, hence facilitating its membership in the zone ${ }^{7}$.

\section{Acknowledgment}

Special thanks to Michael Artis of University of Manchester and Patrick Crowley of University of Texas A \& M, Corpus Christi help and guidance as well as the anonymous referees for their constructive comments.

\section{References}

Artis, M.; Zhang, W. 1997. International business cycles and the ERM: is there a European business cycle?, International Journal of Finance and Economics 2: 1-16.

http://dx.doi.org/10.1002/(SICI)1099-1158(199701)2:1<1::AID-IJFE31>3.0.CO;2-7

Artis, M.; Zhang, W. 2002. Membership of EMU: a fuzzy clustering analysis of alternative criteria, Journal of Economic Integration 17: 54-79.

Baxter, M.; Stockman, A. C. 1989. Business cycles and the exchange-rate regime, Journal of Monetary Economics 27: 377-400. http://dx.doi.org/10.1016/0304-3932(89)90039-1

Bayoumi, T.; Eichengreen, B. 1994. One money or many? Analyzing the prospects for monetary unification in various parts of the world, in Princeton Studies in International Finance 76. Princeton: International Finance Section, Princeton University.

Bayoumi, T.; Eichengreen, B. 1997. Ever closer to heaven? An Optimum-currency-area index for European countries, European Economic Review 41: 761-770.

http://dx.doi.org/10.1016/S0014-2921(97)00035-4

Bayoumi, T.; Mauro, P. 2001. The suitability of ASEAN for a regional currency arrangement, The World Economy 24(7): 933-954. http://dx.doi.org/10.1111/1467-9701.00390

Boreiko, D. 2003. EMU and accession countries: fuzzy cluster analysis of membership, International Journal of Finance and Economics 8: 309-325. http://dx.doi.org/10.1002/ijfe.216

Botero, J.; Djankov, S.; La Porta, R.; Lopez-de-Silanes, F.; Schleifer, A. 2003. The regulation of labor, Quarterly Journal of Economics 119: 1339-1382. http://dx.doi.org/10.1162/0033553042476215

Calvo, G. A. 1998. Varieties of capital market crises, in Calvo, G.; King, M. (Eds.). The Debt Burden and its Consequences for Monetary Policy. Macmillan.

Edison, H.; Melvin, M. 1990. The determinants and implications of the choice of an exchange rate regime, in Haraf, W. S.; Willett, T. D. (Eds.). Monetary Policy for a Volatile Global Economy. Washington: AEI Press.

Fleming, J. M. 1971. On exchange rate unification, Economic Journal 81: 467-488. http://dx.doi.org/10.2307/2229844

Font-Vilalta, M.; Costa-Font, J. 2006. A note on the feasibility of a monetary area in the East Asia, Asia Europe Journal 4(1): 53-58. http://dx.doi.org/10.1007/s10308-005-0037-z

\footnotetext{
${ }^{7}$ One should be aware that sound public finance is one of the most important factors for sustainability in the eurozone.
} 
Frankel, J.; Rose, A. 1998. The endogeneity of the optimum currency area criteria, Economic Journal 108: 1009-1025. http://dx.doi.org/10.1111/1468-0297.00327

Gerlach, S. 1988. World business cycles under fixed and flexible exchange rates, Journal of Money, Credit and Banking 20: 621-632. http://dx.doi.org/10.2307/1992288

Goto, J.; Hamada, K. 1994. Economic preconditions for Asian regional integration, in Ito, T.; Krueger, A. O. (Eds.). Macroeconomic Linkage: Savings, Exchange Rates, and Capital Flows. Chicago, IL: University of Chicago Press, 359-385.

Ingram, J. 1962. Regional Payments Mechanisms: the Case of Puerto Rico. Chapel Hill: University of North Carolina Press.

Kawai, M.; Takagi, S. 2005. Strategy for a regional exchange rate arrangement in East Asia: analysis, review, and proposal, Global Economic Review 34(1): 22-65.

http://dx.doi.org/10.1080/1226508042000328962

Kenen, P. 1969. A theory of optimum currency areas: an eclectic view, in Mundell, R. A.; Swoboda, A. K. (Eds.). Monetary Problems of the International Economy. Chicago: University of Chicago Press.

Krugman, P. 1990. Policy problems of a monetary union, in de Grauwe, P.; Papademos, L. (Eds.). The European Monetary System in the 1990s. Harlow: Longman.

Markiewicz, A. 2006. Choice of exchange rate regime in transition economies: an empirical analysis, Journal of Comparative Economics 34(3): 484-498.

http://dx.doi.org/10.1016/j.jce.2006.06.004

McKinnon, R. 1963. Optimum currency areas, American Economic Review 53: 717-725.

McKinnon, R. I.; Schnabl, G. 2004. The return to soft dollar pegging in East Asia: mitigating conflicted virtue, International Finance 7(2): 169-201.

http://dx.doi.org/10.1111/j.1367-0271.2004.00135.x

McKinnon, R.; Schnabl, G. 2009. The case for stabilizing China's exchange rate: setting the stage for fiscal expansion, China and World Economy 17: 1-32.

http://dx.doi.org/10.1111/j.1749-124X.2009.01128.x

Mundell, R. 1961. A theory of optimum currency areas, American Economic Review 51: 657-664.

Mundell, R. 2003. Prospects for an Asian currency area, Journal of Asian Economics 14: 1-10. http://dx.doi.org/10.1016/S1049-0078(02)00236-1

Nguyen, T. 2007. East Asian currency area: a fuzzy clustering analysis of homogeneity, Development and Policies Research Center Working Paper No. 10. DPRC, Vietnam.

Quah, C. H. 2011. Can Japan or China replace the US as the monetary anchor for Hong Kong and Macau?, Asia Pacific Business Review. http://dx.doi.org/10.1080/13602381.2011.608822

Quah, C. H. 2012. China and the dollar: an optimum currency area view, Prague Economic Papers (forthcoming).

Quah, C. H.; Crowley, P. M. 2010. Monetary integration in East Asia: a hierarchical clustering approach, International Finance 13(2): 283-309.

http://dx.doi.org/10.1111/j.1468-2362.2010.01264.x

Quah, C. H.; Crowley, P. M. 2012. Which country should be the monetary anchor for East Asia: the US, Japan, or China?, Journal of the Asia Pacific Economy 17(1): 94-112.

http://dx.doi.org/10.1080/13547860.2012.640004

Tavlas, G. 1993. The "new" theory of optimum currency areas, The World Economy 16: 663-685. http://dx.doi.org/10.1111/j.1467-9701.1993.tb00189.x

Vaubel, R. 1978. Strategies for Currency Unification. Tubingen: J. C. B. Mohr. 
Wilson, P.; Choy, K. M. 2007. Prospects for enhanced exchange rate cooperation in East Asia: some preliminary findings from generalized PPP theory, Applied Economics 39(8): 981-995. http://dx.doi.org/10.1080/00036840500497042

Yamashita, E. 2009. Future targets for Asian regional integration, Asia Europe Journal 7(1): 109-125. http://dx.doi.org/10.1007/s10308-008-0217-8

Chee-Heong QUAH is a senior lecturer who in April 2011 completed his Ph.D. in International Business at Faculty of Business and Accountancy, University of Malaya with the thesis entitled "Identification of optimal currency areas in East Asia: A clustering approach". Research interests encompass international economics, monetary integration, financial crisis, and optimum currency areas where works have been published in, for instance, International Finance, Journal of Asia Pacific Economy, and Asia Pacific Business Review. 